Hamburger, J., Crosnier, J., and Dormont, J. (1965). Lancet, 1, 985.

- Vaysse, J., Crosnier, J., Tubiana, M., Lalanne, C. M., Antoine, B., Auvert, J., Soulier, J. P., Dormont, J., Salmon, C. H., Maisonnet, M., Amiel, J. L. (1959). Presse méd., 67, 1771.

Herzenberg, L. A., and Herzenberg, L. A. (1961). Proc. nat. Acad. Sci. (W ash.), 47, 762.

Hume, D. M. (1965). Transplantation Conference, Washington -Jackson, B. T., Zukoski, C. F., Lee, H. M., Kauffman, H. M., and Egdahl, R. H. (1960). Ann. Surg., 152, 354

- Merrill, J. P., Miller, B. F., and Thorn, G. W. (1955). 7. clin. Invest., $34,327$.

Hunter, J.'(1771). The Natural History of the Human Teeth. Printed for J. Johnson, London.

Ibuka, K. (1926). Amer. F. med. Sci., 171, 407, 420

Kountz, S. L., Williams, M. A., Williams, P. L., Kapros, C., and Dempster, W. J. (1963). Nature (Lond.), 199, 257.

Kuss, R., Legrain, M., Mathé, G., Nedey, R., Tubiana, M. Lalanne, C. M., Camey, M., Larrieu, M. J., Schwarzenberg, L., Vourch, C. Desarmenien,
méd., 68, 755

Landsteiner, K. (1900). Z Zbl. Bakt., 27, 357.

Little, C. C. (1924). f. Cancer Res., 8, 75 .

Mann, L. T., Corson, J. M., and Dammin, G. J. (1960). Nature (Lond.), 187,774 .

Marchioro, T. L., Axtell, H. K., LaVia, M. F., Waddell, W. R., and Starzl, T. E. (1964). Surgery, 55, 412

Medawar, P. B. (1944). 7. Anat. (Lond.), 78, 176.

- (1945). Ibid., 79, 157.

Merrill, J. P., Murray, J. E., Harrison, J. H., Friedman, E. A., Dealy, J. B., and Dammin, G. J. (1960). New Engl. F. Med., 262, 1251.

Mowbray, J. F., Cohen, S. L., Doak, P. B., Kenyon, J. R., Owen, K., Percival, A., Porter, K. A., and Peart, W. S. (1965). Brit. med. F., 2, 1387 .
Murray, J. E., Merrill, J. P., Harrison, J. H., Wilson, R. E., and Dammin, G. J. (1963). New Engl. F. Med., 268, 1315.

Palmer, J. F. (editor) (1885). The Works of fohn Hunter, F.R.S., with notes, vol. II, p. 104. Longman, London.

Pierce, J. C., and Varco, R. L. (1963). Surgery, 54, 124.

Reemtsma, K., McCracken, B. H., Schlegel, J. U., Pearl, M. A., Pearce, C. W., DeWitt, C. W., Smith, P. E., Hewitt, R. L., Flinner, R. L., and Creech, O., jun. (1964). Ann. Surg., 160, 384.

Richards, V. (1963). Amer. F. Surg., 105, 147.

Shackman, R. (1965). Minerva urol., 17, 94.

Shackman, R. (196.). Minerva urol., 17, 94.

Simonsen, M. (1965). Lancet, 1, 415 .

Buemann, J., Gammeltoft, A., Jensen, F., and Jørgensen, K. (1953). Acta path. microbiol. Scand., 32, 1.

Snell, G. D. (1948). 7. Genet., 49, 87.

(1953). In The Physiology of Cancer, edited by F. Homburger and W. H. Fishman, p. 338. Hoeber, New York.

- (1957). Ann. Rev. Microbial., 11, 439.

Starzl, T. E. (1965). Transplantation Conference, Washington.

Marchioro, T. L., Dickinson, T. C., Rifkind, D., Stonington, O. G., and Waddell, W. R. (1964a). Arch. Surg., 89, 87.

and Weters, G. N., Kirkpatrick, C. H.,Wilson, W. E C Porter, K. A., Rifkind, D., Ogden, D. A., Hitchcock C. R., and Waddell, K. A., Rifkind, D., Ogden, D. A., Hitch

W. R. Rifkind, D., Holmes, J. H., Rowlands, D. T., and Waddell, W. R. (1964c). Surgery, 56, 296.

Vredevoe, D. L., Hutt, M. P., Ogden, D. A., and Waddell, W. R. (1965). Ann. Surg., 162, 749 .

Weaver, J. M., Algire, G. H., and Prehn, R. T. (1955). f. nat. Cancer Inst., 15, 1737 .

Woodruff, M. F. A., Fox, M., Buckton, K. A., and Jacobs, P. A. (1962). Lancet, 1, ig2.

\title{
Treatment of Acute Leukaemia in Adults : Comparison of Steroid and Mercaptopurine Therapy, Alone and in Conjunction
}

\section{Second Report to the Medical Research Council of the Working Party* on the Evaluation of Different Methods of Therapy in Leukaemia}

Brit. med. f., 1966, 1, 1383-1389

In its first report to the Medical Research Council (1963) the Working Party found that the administration of prednisone at a daily dose of $250 \mathrm{mg}$., in conjunction with mercaptopurine at a daily dose of $2.5 \mathrm{mg}$. $/ \mathrm{kg}$. of body weight, was harmful. This " high-dose" steroid schedule was therefore discontinued. The other two schedules (mercaptopurine at a daily dose of $2.5 \mathrm{mg} . / \mathrm{kg}$. of body weight and mercaptopurine at the same dose in combination with prednisone at a daily dose of 40 mg.) were retained, and a further schedule was instituted in which prednisone alone was administered at a daily dose of $40 \mathrm{mg}$. to allow the comparison of mercaptopurine and steroids, alone and in combination.

The procedure for the admission of patients to the second trial and that for the dispatch of bone-marrow films to Dr. F. G. J. Hayhoe were the same as in the first trial. One hundred and fifty patients were admitted to the trial between 15 September 1961 and 3 September 1963 ; 47 were allocated to the "prednisone alone" schedule, 51 to the "mercaptopurine alone" schedule, and 52 to the "combined drugs" schedule. A preliminary analysis showed that the survival curves of the groups of patients who were allocated to the corresponding treatment schedules in the first and second

* The members of the Working Party are: Professor L. J. Witts (chairman), Dr. E. K. Blackburn, Dr. S. T. Callender, Professor J. V. Dacie, Professor W. M. Davidson, Dr. W. R. S. Doll, Dr. C. E. Easson, Dr. J. R. Fountain, Dr. F. G. J. Hayhoe, Dr. C. A. Holman, Dr. M. C. Pike, Dr. L. S. Sacker, Sir Ronald Bodley Scott, Dr. R. B. Thompson, Professor G. Wetherley-Mein, and Dr. D. A. G. Galton (secretary). Dr. R Saracci, a visiting research worker from Pisa at the M.R.C. Statistical Research Unit, assisted both with the statistical analysis and with the writing of this report. trials were almost identical, and for this report the cases in the two trials have been considered together. Thus there were four groups of cases representing 258 patients allocated to four treatment schedules as follows : (1) prednisone alone (at $40 \mathrm{mg}$. daily) -47 patients (second trial only); (2) mercaptopurine alone (at $2.5 \mathrm{mg}$. $/ \mathrm{kg}$. of body weight daily)86 patients (first and second trials); (3) mercaptopurine (at $2.5 \mathrm{mg}$. $/ \mathrm{kg}$. of body weight daily) and prednisone (at $40 \mathrm{mg}$. daily)-88 patients (first and second trials); (4) mercaptopurine (at $2.5 \mathrm{mg}$. $/ \mathrm{kg}$. of body weight daily) and prednisone (at $250 \mathrm{mg}$. daily)-37 patients (first trial only).

These schedules were to apply essentially to the first eight weeks of treatment, after which time treatment was to be at the discretion of the consulting physician. The mercaptopurine therapy was to be administered for the whole eightweek period or until a remission was obtained. The steroid therapy at the $250-\mathrm{mg}$. level was to be administered for two weeks ; the dosage was then to be progressively reduced and the administration discontinued. In the first trial the steroid therapy at the 40-mg. level was to be continued for three weeks before being progressively reduced and stopped; in the second trial, however, the physicians were asked to maintain the steroid therapy at the $40-\mathrm{mg}$. level for at least four weeks, and if possible for eight weeks. The 88 patients in the treatment schedule of $40 \mathrm{mg}$. of prednisone plus mercaptopurine are therefore a "mixed" group; nevertheless, the survival curves of its component groups were so similar that there seemed no point in regarding the two components separately. In both trials all patients received antibiotics, blood transfusions, and other supportive treatment as required. 
In the report of the first trial, treatments 2,3 , and 4 were designated $\mathrm{O}, \mathrm{L}$, and $\mathrm{H}$ respectively. In this report the four treatment schedules are often referred to as steroid-alone, mercaptopurine-alone, combined-treatment (normal-steroid), and combined-treatment (high-steroid) schedules respectively.

In the analysis of the cases in the first trial all were classified as either "myeloid" or "lymphoblastic," even though three of them had to be forced into one or other type. For the purpose of analysis, diagnoses of myeloblastic, promyelocytic, myelomonocytic, and monocytic leukaemia and of erythroleukaemia or erythraemic mye'osis were grouped together as myeloid leukaemia. In the present analysis six cases in which the diagnostic difficulty was not resolved have been omitted because the survival curves of the two types are so different that their inclusion could help only to obscure the picture. Two cases of plasma-cell leukaemia were also omitted for the same reason. The final numbers analysed in each treatment category are given in Table I, and these 250 patients are the subject of the remainder of this report.

TABLE I.-250 Cases of Acute Leukaemia in Adults. Distribution by Cytological Type and Treatment

\begin{tabular}{|c|c|c|}
\hline Treatment* & Myeloid & Lymphoblastic \\
\hline 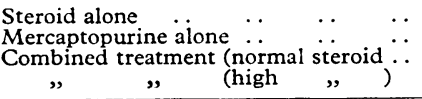 & $\begin{array}{l}39 \\
71 \\
70 \\
30\end{array}$ & $\begin{array}{r}7 \\
13 \\
13 \\
7\end{array}$ \\
\hline Total $\quad \ldots \quad \ldots$ & 210 & 40 \\
\hline
\end{tabular}

* Mercaptopurine: $2.5 \mathrm{mg} . / \mathrm{kg}$. of body weight daily; normal steroid/steroid alone: $40 \mathrm{mg}$. daily; high steroid: $250 \mathrm{mg}$. daily.

The information collected from each patient included the clinical history and physical signs at presentation. The initial haematological findings recorded were the haemoglobin concentration, the platelet count, the total and differential leucocyte counts, and the cytological type as determined from bone-marrow films by Dr. Hayhoe. As in the first trial, Dr. Hayhoe's diagnosis sometimes differed from that of the local pathologist, but with the few exceptions already referred to these differences were resolved by direct consultation between them.

Because of the uncertainty whether the counts recorded on the first day of treatment were always performed on blood taken before the first dose was administered the readings chosen for analysis were, when possible, those obtained one to six days before the start of treatment (the readings chosen being those for the day nearest to the start of treatment). The counts recorded for the first day of treatment were used only when no previous counts were available, or when previous counts had been made seven or more days before the first day of treatment. When possible the values chosen for the haemoglobin concentration and leucocyte and platelet counts were obtained from an examination made on the same day, but occasionally a platelet count had not been made until the first day of treatment, the other investigations having been performed earlier. When the patient had received blood transfusions before treatment, the accepted value for the haemoglobin concentration was that obtained before the administration of the first transfusion, except in a few instances in which pre-transfusion values were not known.

Initial platelet counts were not available for 11 patients and haemoglobin values for three. These missing values were estimated from two multiple regression equations. ${ }^{1}$

1 Patients for whom even a single pretreatment value was missing would otherwise have had to be omitted from the analysis of the effect of pretreatment factors on survival time. The method of estimation amounts to assuming that the platelet count (or haemoglobin value) can be represented simply as dependent on all the other presenting can beatures except for a random component with an average value of features except for a randence relation has been determined with the zero. use of the data of the patients for from this relation with the use of the values of all the other presenting features of this patient.
The follow-up data included clinical and haematological findings and details of all forms of treatment administered. Follow-up records were made according to the discretion of each observer, no set times being required for the recording of particular observations.

The four treatment schedules involved adherence to the first planned treatment for eight weeks. One hundred and thirtyeight patients died within this period, 13 of whom also received other treatments-for example, prednisone if they were on mercaptopurine. Of the 112 patients who survived eight weeks or more, 13 received other treatments-that is, within the eightweek period. After the first eight weeks the physician was free to vary the treatment as he thought necessary, and in fact most patients came to receive both mercaptopurine and prednisone. Individual patients also received other antimitotic drugs.

\section{Comparison of Myeloid and Lymphoblastic Cases}

Tables II and III show the main presenting characteristics of the myeloid and lymphoblastic cases. We note that the

TABLE 2.-Distribution of Presenting Features by Cytological Type

\begin{tabular}{|c|c|c|c|c|c|c|}
\hline & Fontra & & & & Ly & lastic \\
\hline А & & & No. & $\%$ & No. & $\%$ \\
\hline Age & $\left\{\begin{array}{l}14-19 \\
20-29 \\
30-39 \\
40-49 \\
50-59 \\
60-69 \\
70-79 \\
80+\end{array}\right.$ & $\begin{array}{l}\ldots \\
\cdots \\
\cdots \\
\cdots \\
\cdots \\
\cdots\end{array}$ & $\begin{array}{l}19 \\
19 \\
24 \\
38 \\
39 \\
36 \\
22 \\
13\end{array}$ & $\begin{array}{r}9.0 \\
9.0 \\
11.4 \\
18 \cdot 1 \\
18.6 \\
17 \cdot 1 \\
10.5 \\
6 \cdot 2\end{array}$ & $\begin{array}{r}11 \\
9 \\
3 \\
5 \\
2 \\
7 \\
3 \\
0\end{array}$ & $\begin{array}{r}27.5 \\
22.5 \\
7.5 \\
12.5 \\
5.0 \\
17.5 \\
7.5 \\
0.0\end{array}$ \\
\hline & & & 210 & $99 \cdot 9$ & 40 & $100 \cdot 0$ \\
\hline$\underset{(\mathrm{g} . / 100 \mathrm{ml} .)}{\text { Haemoglobin }}$ & $\left\{\begin{array}{l}0-2 \cdot 9 \\
3 \cdot 0-5 \cdot 9 \\
6 \cdot 0-8 \cdot 9 \\
9 \cdot 0-11 \cdot 9 \\
12 \cdot 0+\end{array}\right.$ & $\begin{array}{l}\cdots \\
\cdots \\
\cdots \\
\cdots\end{array}$ & $\begin{array}{r}2 \\
57 \\
105 \\
38 \\
8\end{array}$ & $\begin{array}{r}1 \cdot 0 \\
27 \cdot 1 \\
50 \cdot 0 \\
18 \cdot 1 \\
3 \cdot 8\end{array}$ & $\begin{array}{r}1 \\
10 \\
21 \\
7 \\
2\end{array}$ & $\begin{array}{r}0 \cdot 0 \\
25 \cdot 0 \\
52 \cdot 5 \\
17.5 \\
5.0\end{array}$ \\
\hline & & & 210 & $100 \cdot 0$ & 40 & $100 \cdot 0$ \\
\hline $\begin{array}{c}\text { Neutrophil } \\
\text { count } \\
\text { (000's/c.mm.) }\end{array}$ & $\left\{\begin{array}{l}0-0 \cdot 9 \\
1 \cdot 0-1 \cdot 9 \\
2 \cdot 0-2 \cdot 9 \\
3 \cdot 0+\end{array}\right.$ & $\begin{array}{l}\cdots \\
\cdots \\
\cdots\end{array}$ & $\begin{array}{l}97 \\
33 \\
17 \\
63\end{array}$ & $\begin{array}{r}46 \cdot 2 \\
15 \cdot 7 \\
8 \cdot 1 \\
30 \cdot 0\end{array}$ & $\begin{array}{r}24 \\
6 \\
0 \\
10\end{array}$ & $\begin{array}{r}60 \cdot 0 \\
15 \cdot 0 \\
0 \cdot 0 \\
25 \cdot 0\end{array}$ \\
\hline & & 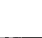 & 210 & $100 \cdot 0$ & 40 & $100 \cdot 0$ \\
\hline $\begin{array}{c}\text { Blast-cell } \\
\text { count } \\
\left(000^{\prime} \mathrm{s} / \mathrm{c} \mathrm{mm} .\right)\end{array}$ & $\left\{\begin{array}{l}0-1 \cdot 9 \\
2 \cdot 0-7 \cdot 9 \\
8 \cdot 0-31 \cdot 9 \\
32 \cdot 0+\end{array}\right.$ & $\begin{array}{l}\cdots \\
\cdots \\
\cdots\end{array}$ & $\begin{array}{l}76 \\
43 \\
42 \\
49\end{array}$ & $\begin{array}{l}36 \cdot 2 \\
20 \cdot 5 \\
20 \cdot 0 \\
23 \cdot 3\end{array}$ & $\begin{array}{r}11 \\
7 \\
11 \\
11\end{array}$ & $\begin{array}{l}27.5 \\
17.5 \\
27.5 \\
27.5\end{array}$ \\
\hline & & 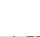 & 210 & $100 \cdot 0$ & 40 & $100 \cdot 0$ \\
\hline $\begin{array}{c}\text { Other } \\
\text { leucocytes } \\
(000 \text { 's/c.mm. })\end{array}$ & $\begin{array}{l}0-1 \cdot 9 \\
2 \cdot 0-7 \cdot 9 \\
8 \cdot 0-31 \cdot 9 \\
32 \cdot 0+\end{array}$ & $\begin{array}{l}\cdots \\
\cdots \\
\cdots\end{array}$ & $\begin{array}{l}69 \\
74 \\
37 \\
30\end{array}$ & $\begin{array}{l}32 \cdot 9 \\
35 \cdot 2 \\
17 \cdot 6 \\
14 \cdot 3\end{array}$ & $\begin{array}{r}10 \\
18 \\
9 \\
3\end{array}$ & $\begin{array}{r}25 \cdot 0 \\
45 \cdot 0 \\
22 \cdot 5 \\
7 \cdot 5\end{array}$ \\
\hline & & & 210 & $100 \cdot 0$ & 40 & $100 \cdot 0$ \\
\hline $\left.\begin{array}{c}\text { Platelet } \\
\text { count } \\
(000 \text { 's } / \text { c.mm. })\end{array}\right\}$ & $\left\{\begin{array}{c}0-24 \\
25-49 \\
50-74 \\
75-99 \\
100-149 \\
150+\end{array}\right.$ & $\begin{array}{l}\cdots \\
\cdots \\
\cdots \\
\cdots\end{array}$ & $\begin{array}{l}42 \\
45 \\
38 \\
20 \\
33 \\
32\end{array}$ & $\begin{array}{r}20 \cdot 0 \\
21 \cdot 4 \\
18 \cdot 1 \\
9 \cdot 5 \\
15 \cdot 7 \\
15 \cdot 2\end{array}$ & $\begin{array}{r}18 \\
8 \\
4 \\
4 \\
2 \\
4\end{array}$ & $\begin{array}{r}45 \cdot 0 \\
20 \cdot 0 \\
10 \cdot 0 \\
10 \cdot 0 \\
5 \cdot 0 \\
10 \cdot 0\end{array}$ \\
\hline & l & & 210 & $99 \cdot 9$ & 40 & $100 \cdot 0$ \\
\hline
\end{tabular}

TABle III.-Distribution of Presenting Signs by Cytological Type

\begin{tabular}{|c|c|c|c|c|c|}
\hline \multirow{2}{*}{\multicolumn{2}{|c|}{$\begin{array}{l}\text { Presenting } \\
\text { Sign }\end{array}$}} & \multicolumn{2}{|c|}{$\begin{array}{c}\text { Myeloid } \\
\text { (210 Patients) }\end{array}$} & \multicolumn{2}{|c|}{$\begin{array}{l}\text { Lymphoblastic } \\
\text { (40 Patients) }\end{array}$} \\
\hline & & No. & $\%$ & No. & $\%$ \\
\hline $\begin{array}{l}\text { Haemorrhage } . . \\
\text { Infection } \\
\text { Swollen gums } . . \\
\text { Enlarged nodes } \\
\text { skleen } \\
\text { Skin involvement }\end{array}$ & $\begin{array}{l}\ldots \\
\cdots \\
\cdots \\
\cdots\end{array}$ & $\begin{array}{r}100 \\
102 \\
19 \\
82 \\
78 \\
9\end{array}$ & $\begin{array}{r}47 \cdot 6 \\
48 \cdot 6 \\
9 \cdot 0 \\
39 \cdot 0 \\
37 \cdot 1 \\
4 \cdot 3\end{array}$ & $\begin{array}{r}25 \\
18 \\
0 \\
27 \\
30 \\
1\end{array}$ & $\begin{array}{r}62.5 \\
45.0 \\
0.0 \\
67.1 \\
75.0 \\
2.5\end{array}$ \\
\hline $\begin{array}{c}\text { Type } \\
\text { of } \\
\text { onset }\end{array}\left\{\begin{array}{l}\text { Acute } \\
\text { Insidious } \\
\text { Accidental }\end{array}\right.$ & $\begin{array}{l}\ldots \\
\cdots\end{array}$ & $\begin{array}{r}124 \\
74 \\
12\end{array}$ & $\begin{array}{r}59 \cdot 0 \\
35 \cdot 2 \\
5 \cdot 7\end{array}$ & $\begin{array}{r}30 \\
10 \\
0\end{array}$ & $\begin{array}{r}75 \cdot 0 \\
25 \cdot 0 \\
0 \cdot 0\end{array}$ \\
\hline Sex $\left\{\begin{array}{l}\text { Male } . . \\
\text { Female }\end{array}\right.$ & $\begin{array}{l}\cdots \\
\cdots\end{array}$ & $\begin{array}{l}107 \\
103\end{array}$ & $\begin{array}{l}51 \cdot 0 \\
49 \cdot 0\end{array}$ & $\begin{array}{l}23 \\
17\end{array}$ & $\begin{array}{l}57 \cdot 5 \\
42 \cdot 5\end{array}$ \\
\hline
\end{tabular}

* Acute $=$ acute onset without preceding symptoms. Accidental = Discovery of leukemia by chance in symptomless patients. 
major differences between them are in their age and plateletcount distributions and in the frequency with which they present with swollen gums, enlarged nodes, and enlarged spleen. There was a tendency for the lymphoblastic disease to occur in younger subjects ; low platelet counts were more often a presenting feature of lymphoblastic leukaemia. Swollen gums occurred only in the myeloid disease (in fact all these cases were of monocytic or myelomonocytic leukaemia); palpable enlargement of the lymph nodes and palpable enlargement of the spleen presented about twice as often in lymphoblastic leukaemia. $\left(\chi^{2}\right.$ tests give: for age, $\mathrm{P}<0.001^{2}$; for platelets, $P<0.005$; for swollen gums, $P=0.03$; for enlarged nodes, $\mathbf{P}<0.005$; for enlarged spleen, $\mathrm{P}<0.001$.)

Fig. 1 shows the survival curves (measured from the start of treatment) of the 250 patients classified according to cytological type: $50 \%$ of the myeloid patients survived for 37 days or more, whereas $50 \%$ of the lymphoblastic patients survived for 112 days or more. These survival curves are so different that the fate of the two groups of patients will be considered separately.

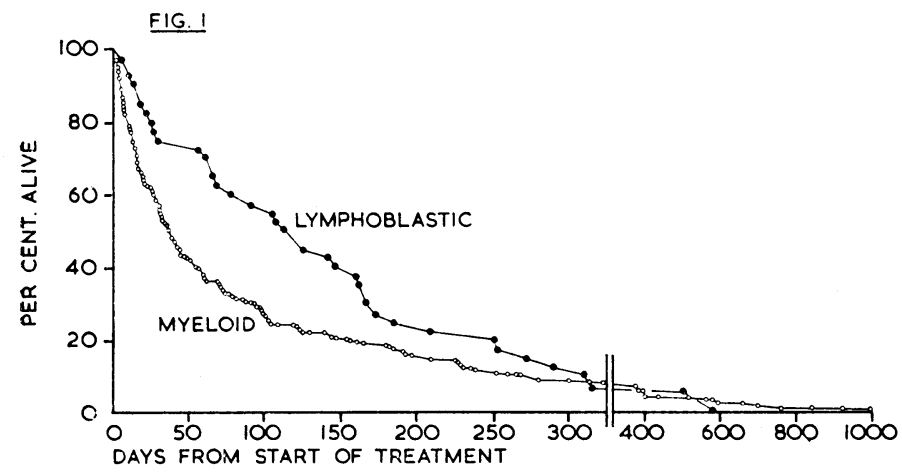

FIG. 1.-Survival curves of 210 patients suffering from acute myeloid leukaemia and of 40 patients suffering from acute lymphoblastic leukaemia (patients aged 14 years and over).

\section{Analysis of Myeloid Cases}

Fig. 2 shows the survival curves of the myeloid cases by treatment schedule. The curves suggest a slight superiority of steroid alone to mercaptopurine alone, and a superiority of steroid alone and mercaptopurine alone to the combined-treat-

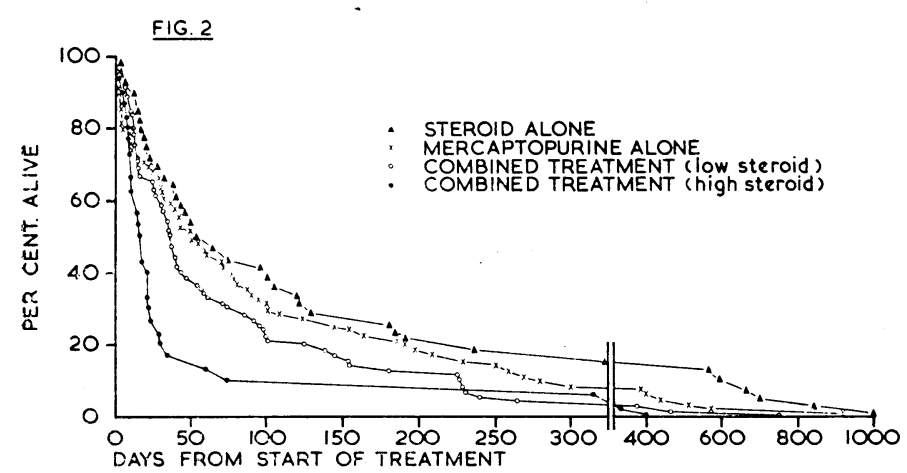

FIG. 2.-Survival curves of 210 patients suffering from acute myeloid leukaemia treated by one of four methods (see text).

ment schedules. A closer inspection shows that the superiority of steroid alone to mercaptopurine alone could have resulted from a larger proportion of very early deaths in the mercaptopurine-alone group. Such early deaths could have resulted either from a grossly unequal distribution of unfavourable pre-

${ }^{2} \mathrm{P}=$ Probability of the occurrence due to chance of a difference as large as or larger than that observed. senting features or from the deleterious effects of mercaptopurine therapy.

The most striking feature of these early deaths was their almost total dependence on a high blast-cell count (Table IV). The mercaptopurine-alone schedule had a relatively high proportion of these bad-risk patients (Table V), but this does not dispose completely of the larger proportion of early deaths with the mercaptopurine-alone schedule, as bad-risk patients in this treatment group also fared worse than the other patients with similar counts (Table VI). The differences shown in Table VI could, however, have easily arisen by chance, and inspection of the haematological changes during the treatment does not suggest a deleterious effect of mercaptopurine in the first three days. Furthermore, the total survival curve for the combinedtreatment (normal-steroid) schedule suggests that steroid and mercaptopurine in combination were less effective than mercaptopurine alone, yet the proportion of early deaths in the combined-treatment (normal-steroid) schedule was lower than in the steroid-alone schedule. For all these reasons we believe that the excess of early deaths in the mercaptopurine-alone schedule was fortuitous, and that a truer picture of the effect of therapy is obtained when we ignore the patients who died within the first three days.

TABLE IV.-Relationship of Blast-cell Count to "Early" Death in

\begin{tabular}{|c|c|c|c|c|}
\hline \multirow{2}{*}{\multicolumn{2}{|c|}{$\begin{array}{l}\text { Blast-cell } \\
\text { Count }\end{array}$}} & \multicolumn{2}{|c|}{$\begin{array}{l}\text { Died in First } 3 \text { Days after } \\
\text { Start of Treatment }\end{array}$} & \multirow{2}{*}{ Total } \\
\hline & & Yes & No & \\
\hline \multirow[t]{2}{*}{$\begin{array}{l}25,000 / \text { c.mm. } \\
\geqslant 25,000 / \text { c.mm. }\end{array}$} & $\begin{array}{ll}. & . \\
. & \end{array}$ & $\begin{array}{r}3 \\
15\end{array}$ & $\begin{array}{r}151 \\
41\end{array}$ & $\begin{array}{r}154 \\
56\end{array}$ \\
\hline & & 18 & 192 & 210 \\
\hline
\end{tabular}

TABLE V.-Initial Blast-cell Count and Treatment in Patients with Myeloid Leukaemia

\begin{tabular}{|c|c|c|c|}
\hline \multirow{2}{*}{ Treatment* } & \multicolumn{2}{|c|}{ Patients with Blast-cell Counts } & \multirow{2}{*}{ Total } \\
\hline & $=25,000 /$ c.mm. & $\geqslant 25,000 / \mathrm{c} \cdot \mathrm{mm}$ & \\
\hline \multirow{3}{*}{ 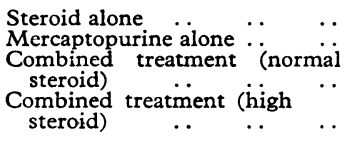 } & $\begin{array}{l}32(82 \%) \\
47(66 \%)\end{array}$ & $\begin{array}{r}7(18 \%) \\
23(34 \%)\end{array}$ & $\begin{array}{l}39(100 \%) \\
71(100 \%)\end{array}$ \\
\hline & $52(74 \%)$ & $18(26 \%)$ & $70(100 \%)$ \\
\hline & $23(77 \%)$ & $7(23 \%)$ & $30(100 \%)$ \\
\hline
\end{tabular}

* Mercaptopurine: $2.5 \mathrm{mg} . / \mathrm{kg}$. of body weight daily; normal steroid/steroid alone: $40 \mathrm{mg}$. daily; high steroid: $250 \mathrm{mg}$. daily.

TABLE VI.-Relationship Between "Early" Death and Treatment for Patients with Myeloid Leukaemia with Initial Blast-cell Count of 25,000/c.mm. or More

\begin{tabular}{|c|c|c|c|}
\hline \multirow{2}{*}{ Treatment* } & \multicolumn{2}{|c|}{$\begin{array}{c}\text { Died in First } 3 \text { Days after } \\
\text { Start of Treatment }\end{array}$} & \multirow{2}{*}{ Total } \\
\hline & Yes & No & \\
\hline $\begin{array}{l}\text { Steroid alone } . . \\
\text { Mercaptopurine alone } \\
\text { Combined treatment }\end{array} \quad \begin{array}{l}\text { (normal } \\
\text { (n) }\end{array}$ & $\begin{array}{l}2(29 \%) \\
9(38 \%)\end{array}$ & $\begin{array}{l}5(71 \%) \\
15(62 \%)\end{array}$ & $\begin{array}{r}7(100 \%) \\
24(100 \%)\end{array}$ \\
\hline $\begin{array}{c}\text { steroid) } \\
\text { Combined } \\
\text { treatment }\end{array}$ & $3(17 \%)$ & $15(83 \%)$ & $18(100 \%)$ \\
\hline $\begin{array}{lll}\cdots & \cdots & \end{array}$ & $1(14 \%)$ & $6(86 \%)$ & $7(100 \%)$ \\
\hline
\end{tabular}

* Mercaptopurine: $2.5 \mathrm{mg} . / \mathrm{kg}$. of body weight daily; normal steroid/steroid alone: $40 \mathrm{mg}$. daily; high steroid: $250 \mathrm{mg}$. daily.

Fig. 3 shows the survival curves of the 192 myeloid patients who survived for three days or more, and all subsequent analyses are based on the results in these patients unless otherwise specified.

To test the statistical significance of the differences between these survival curves it is advantageous to change the scale on which survival time was measured, so as to make the distribution of survival times conform more nearly to the "normal" distribution. This is a standard statistical procedure, the details of which are described in the Appendix.

Fig. 4 shows the survival curves plotted on this transformed scale on normal probability paper. A truly normal distribution appears as a straight line on this paper, and with this trans- 
formation we see that the condition of approximation to a normal distribution is satisfied. All calculations on survival time are therefore made on the transformed scale.

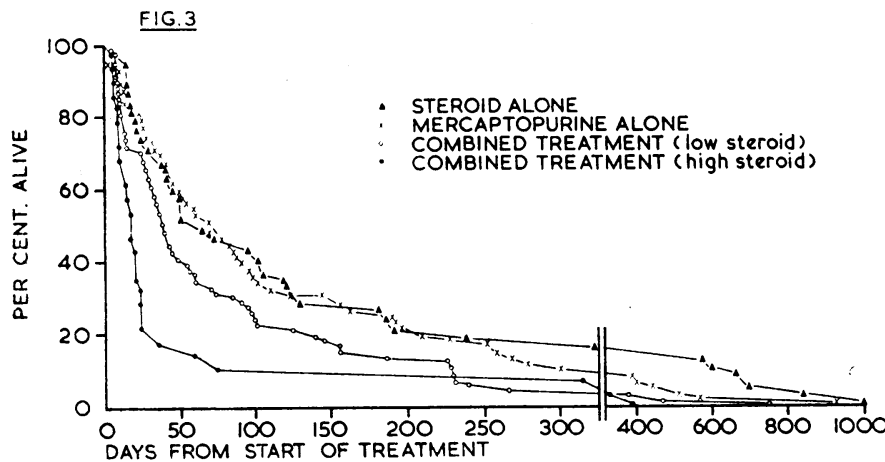

FIG. 3.- Survival curves of 192 patients suffering from acute myeloid leukaemia treated by one of four methods. 18 patients who died before the fourth day after the start of treatment are omitted (see text).

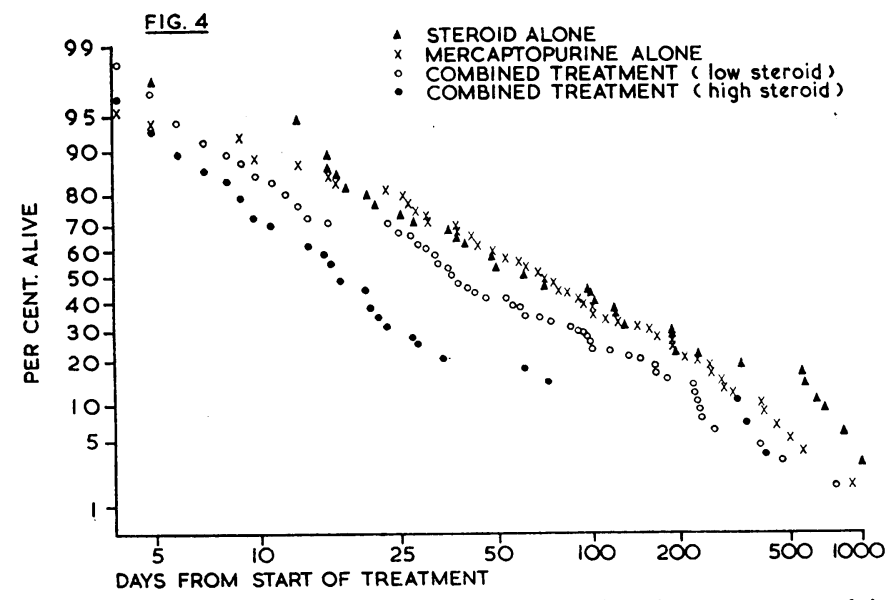

FIG. 4.-Survival curves of 192 patients suffering from acute myeloid leukaemia treated by one of four methods plotted on "normal" probability paper. The time scale has been transformed to make the survival-

time distributions as near normal as possible (see Appendix).

The estimated median survivals for groups steroid alone, mercaptopurine alone, combined treatment (normal steroid), and combined treatment (high steroid) are $71.5,61.2,40.0$, and 21.0 days respectively from the start of treatment. The differences between each pair of treatments are shown in Table VII. The survival curve for the steroid-alone schedule is thus clearly better than for the combined-treatment (high-steroid) schedule. The difference between the steroid-alone schedule and the combined-treatment (normal-steroid) schedule is substantial and statistically significant $(P=0.02)$, but the difference between the steroid-alone schedule and the mercaptopurinealone schedule could easily have arisen by chance. In our first report (M.R.C., 1963) the superiority of the mercaptopurinealone schedule to the combined-treatment (normal-steroid)

TABLE VII.-Unadiusted Differences Between Estimated Median Survival Times for 192 Patients with Myeloid Leukaemia who Survived for Four or More Days From the Start of Treatment

\begin{tabular}{|c|c|c|}
\hline $\begin{array}{l}\text { Treatment* } \\
\text { Difference }\end{array}$ & $\begin{array}{l}\text { Difference between } \\
\text { Medians }\end{array}$ & Probability $†$ \\
\hline $\begin{array}{l}\text { Steroid alone-mercaptopurine alone } \\
\text {-combined treatment }\end{array}$ & $+10 \cdot 3$ & $0 \cdot 56$ \\
\hline $\begin{array}{l}\text { (normal"steroid) } \\
\text { Steroid alone-combined treatment }\end{array}$ & +31.5 & 0.02 \\
\hline $\begin{array}{l}\text { Steroid alone- comolided } \\
\text { (high steroid) }\end{array}$ & $+50 \cdot 5$ & 0.00007 \\
\hline $\begin{array}{l}\text { Mercaptopurine alone-combined treat- } \\
\text { ment (normal steroid) }\end{array}$ & $+21 \cdot 2$ & 0.06 \\
\hline $\begin{array}{l}\text { Mercaptopurine alone- combined treat- } \\
\text { ment (high steroid) }\end{array}$ & $+40 \cdot 3$ & 0.0001 \\
\hline $\begin{array}{l}\text { Combined treatment (normal steroid) - } \\
\text { combined treatment (high steroid) } \ldots\end{array}$ & $+19 \cdot 1$ & 0.02 \\
\hline
\end{tabular}

* Mercaptopurine: $2.5 \mathrm{mg}$. $/ \mathrm{kg}$. of body weight daily; normal steroid/steroid alone: $40 \mathrm{mg}$. daily; high steroid: $250 \mathrm{mg}$. daily

+ Probability of an occurre schedule was of doubtful significance, but survival in both groups was superior to the combined-treatment (high-steroid) schedule. We now have double the numbers in the first trial for both the mercaptopurine-alone schedule and the combinedtreatment (normal-steroid) schedule, and the difference between them is now very suggestive.

\section{Pre-treatment Features of Possible Prognostic Importance}

We consider now the distribution of the pre-treatment features of the cases in each schedule which might by chance have led to the differences in the survival curves, independently of the effect of treatment.

The features recorded at the start of treatment that were taken into account as of possible prognostic importance are age and sex of patient, type of clinical onset, presence of infection, presence of haemorrhagic manifestations, palpable lymphnode enlargement, palpable spleen, skin infiltrations, swollen gums, haemoglobin concentration, and the logarithms of the neutrophil count, blast-cell count, count of "other leucocytes" -that is, the total leucocyte count minus the sum of the neutrophil and blast-cell counts-and platelet count.

By means of a series of scatter diagrams we examined the association of each feature with the transformed survival time. In each diagram the survival time of each patient was subtracted from the median survival time of his treatment group to eliminate treatment effects (for the purposes of illustration these differences are added to a fixed median survival time of 61.2 days-equal to the median survival time of the mercaptopurinealone schedule). The highest correlation $(0.27)$ is with the logarithm of the initial neutrophil count $(P=0.0002)$, and the scatter diagram of these results is shown in Fig. 5. It is apparent that even this feature has remarkably little association with survival, ${ }^{3}$ and the reduction in the spread of the observations-that is, in their standard deviation-after allowing for this feature is only $3.4 \%$. The correlation $(-0.24)$ with age is also highly significant $(P=0.001$, reduction in spread of observations $2.6 \%$ ), but the only other association approaching statistical significance was that of longer survival with an enlarged spleen $(P=0.08$, reduction in spread of observations $0.6 \%$ ).

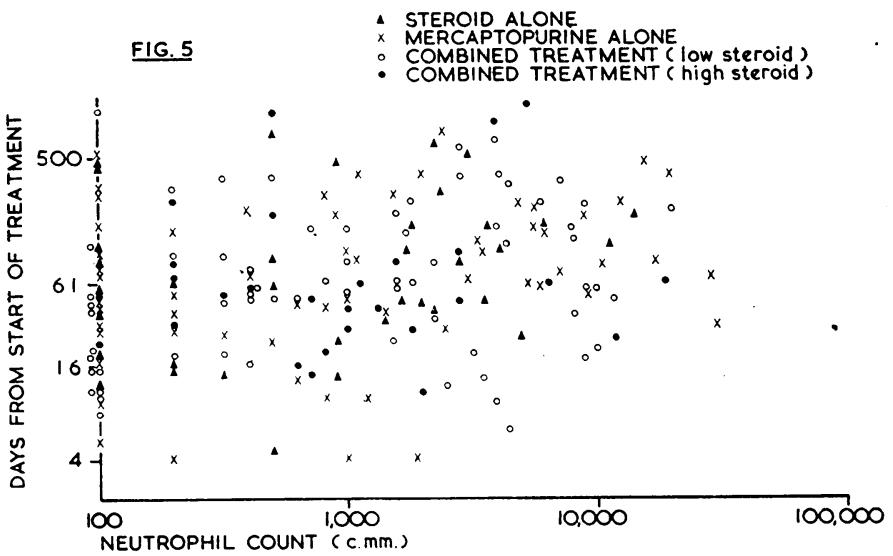

FIG. 5.-Scatter diagram of initial neutrophil count against survival time for 192 patients suffering from acute myeloid leukaemia (see Appendix for transformation of survival-time scale).

Taken together the logarithm of the neutrophil count and age accounted for $6.4 \%$ of the spread of the survival times. After both of these had been taken into account the association of an enlarged spleen was no longer noticeable and the logarithm of the blast-cell count was the only remaining feature significantly $(P=0.01)$ related to survival-the percentage of the spread accounted for being increased by it from $6.4 \%$ to $7.7 \%$.

\footnotetext{
${ }^{3}$ Considering only patients who survived four or more days.
} 
In this case, as would be anticipated, the correlation was negative; the higher the blast-cell count was the worse the prognosis.

When all features were considered together the reduction in the standard deviation of an individual survival time was $8.6 \%$, and though this is not large it still may be worth while to adjust the crude median survival times for each treatment schedule for the pre-treatment feature differences. The adjusted median survival times for the steroid-alone, mercaptopurine-alone, combined-treatment (normal-steroid), and combined-treatment (high-steroid) groups are respectively 70.0, 61.6, 40.8, and 20.7 days. The adjusted differences between these treatment schedules are given in Table VIII, and are seen to be almost identical with the crude values given in Table VII.

TABLE VIII.-Adjusted Differences Between Estimated Median Survival Times for 192 Patients with Myeloid Leukaemia who Survived for Four or More Days from the Start of Treatment

\begin{tabular}{|c|c|c|}
\hline $\begin{array}{l}\text { Treatment* } \\
\text { Difference }\end{array}$ & $\begin{array}{l}\text { Difference between } \\
\text { Medians }\end{array}$ & Probability \\
\hline 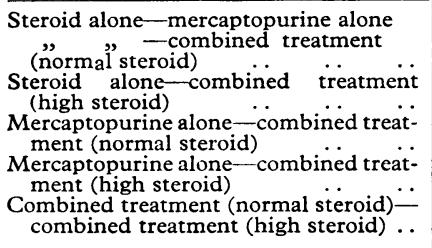 & $\begin{array}{l}+8 \cdot 4 \\
+29 \cdot 2 \\
+49 \cdot 3 \\
+20 \cdot 8 \\
+40 \cdot 9 \\
+20 \cdot 2\end{array}$ & $\begin{array}{l}0.62 \\
0.03 \\
0.00002 \\
0.05 \\
0.00002 \\
0.006\end{array}$ \\
\hline
\end{tabular}

* Mercaptopurine: $2.5 \mathrm{mg}$./kg. of body weight daily; normal steroid/steroid

alone: $40 \mathrm{mg}$. daily; high steroid: $250 \mathrm{mg}$. daily.
† Probability of an occurrence due to chance of an absolute difference as large as or larger than that observed.

\section{Analysis of Lymphoblastic Cases}

Fig. 6 shows the survival curves of the lymphoblastic cases by treatment schedule. To test the statistical significance of the differences between these survival curves it is again advantageous to change the scale on which survival time was measured to make the distribution of survival times conform more nearly to the "normal" distribution, as was done previously for the myeloid cases (see Appendix). All calculations on the survival times of lymphoblastic cases were therefore made on the transformed scale.

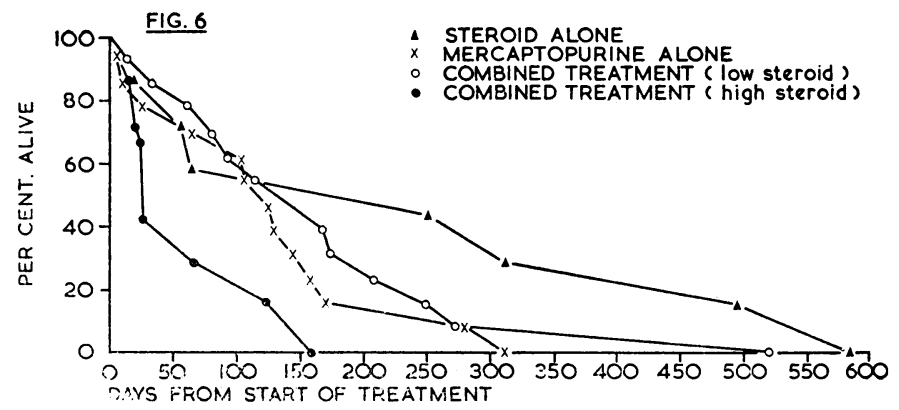

FIG. 6.- Survival curves of 40 patients suffering from acute lymphoblastic leukaemia treated by one of four methods (see text).

The estimated median survivals for the steroid-alone, mercaptopurine-alone, combined-treatment (normal-steroid), and combined-treatment (high-steroid) groups are respectively $176.4,95.3,127.8$, and 44.6 days, and the differences between them are given in Table IX. The superiority of the steroidalone schedule to the combined-treatment (high-steroid) schedule is large and statistically significant $(P=0.03)$. The superiority of the combined-treatment (normal-steroid) schedule to the combined-treatment (high-steroid) schedule is also substantial and statistically suggestive $(P=0.05)$. The remaining differences between the schedules, though often substantial, could easily have arisen purely by chance-the numbers of patients involved being so small and the estimated median survival times having large standard errors.
TABLE IX.-Unadiusted Differences Between Estimated Median Survival Times for 40 Patients with Lymphoblastic Leukaemia

\begin{tabular}{|c|c|c|}
\hline $\begin{array}{l}\text { Treatment* } \\
\text { Comparison }\end{array}$ & $\begin{array}{l}\text { Difference between } \\
\text { Medians }\end{array}$ & Probabilityf \\
\hline $\begin{array}{l}\text { Steroid alone-mercaptopurine alone } \\
\text { "\# - combined treatment } \\
\text { normal" steroid) } \ldots \\
\text { Steroid alone-combined treatment (high } \\
\text { steroid) } \\
\text { Mercaptopurine alone-combined treat- } \\
\text { ment (normal steroid) } \\
\text { Mercaptopurine alone-combined treat- } \\
\text { ment (high steroid) } \\
\text { Combined treatment (normal steroid) } \\
\text { combined treatment (high steroid) .. }\end{array}$ & $\begin{array}{r}+81 \cdot 1 \\
+48 \cdot 6 \\
+131 \cdot 8 \\
-32 \cdot 5 \\
+50 \cdot 7 \\
+83 \cdot 2\end{array}$ & $\begin{array}{l}0.18 \\
0.49 \\
0.03 \\
0.49 \\
0.18\end{array}$ \\
\hline
\end{tabular}

* Mercaptopurine: $2.5 \mathrm{mg} . / \mathrm{kg}$. of body weight daily. Normal steroid/steroid alone: $40 \mathrm{mg}$. daily. High steroid: $250 \mathrm{mg}$. daily.

$t$ Probability of an occurrence due to chance of an absolute difference as large as or larger than that observed.

\section{Pre-treatment Features of Possible Prognostic Importance}

As in the analysis of the myeloid cases, we examined the association of each feature with the transformed survival time by means of a series of scatter diagrams. In each diagram the survival time of each patient was subtracted from the median survival time of his treatment group to eliminate treatment effects (for the purposes of illustration these differences were added to a fixed median survival time of 95.3 days-equal to the median survival time of the mercaptopurine-alone group). The highest correlation (0.39) is with the presence of a palpably enlarged spleen $(P=0.02)$, for which a scatter diagram is shown (Fig. 7) ; the reduction in the spread of the observations allowing for this factor is $6.4 \%$. The correlation with age $(-0.32)$ is also suggestive $(P=0.06$, reduction in spread of observations $3.8 \%$ ).

\section{FIG. 7}
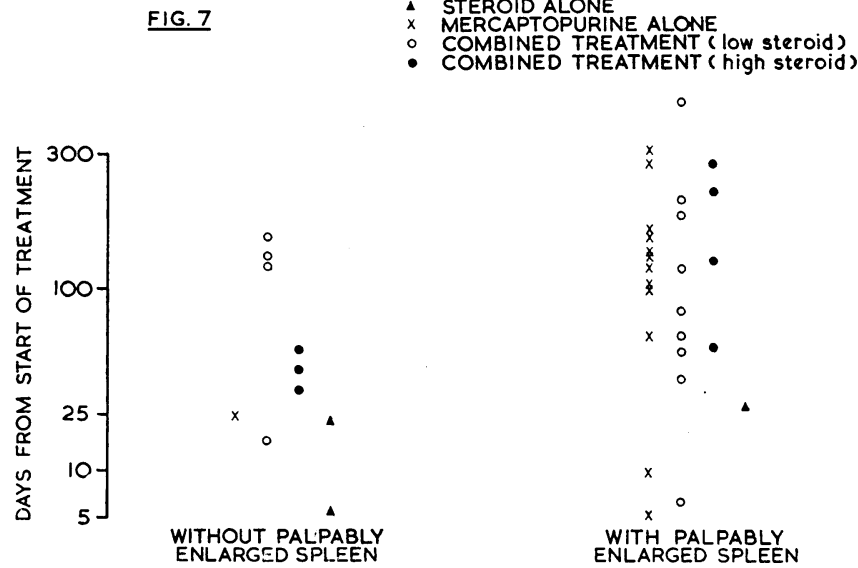

○

FIG. 7.- Scatter diagram of initial presence or absence of a palpably enlarged spleen against survival time for 40 patients suffering from acute lymphoblastic leukaemia (see Appendix for transformation of survival-time

After enlargement of the spleen had been taken into account the association of age was no longer noticeable, and the platelet count was the only remaining feature significantly related to survival $(P=0.05)$ - the percentage of the spread of the survival times accounted for being increased from $6.4 \%$ to $10.3 \%$. As would be anticipated, the correlation was positive: the higher the logarithm of the platelet count was, the longer the survival.

When all features were considered together the reduction in the standard deviation of an individual survival time was $10.7 \%$, and though this is not large it still may be worth while to adjust the crude median survival times for each treatment schedule for the differences in the pre-treatment features. The adjusted median survival times for the steroid-alone, mercaptopurine-alone, combined-treatment (normal-steroid), and combined-treatment (high-steroid) groups are respectively 234.5, $76.3,122.0$, and 53.2 days. The adjusted differences between 
these treatment schedules are given in Table $\mathrm{X}$. The differences between the steroid-alone schedule and the other schedules have been increased, but the superiority to the combined-treatment (high-steroid) schedule is the only one that is at all conclusive. The superiority of the steroid-alone schedule to the mercaptopurine-alone schedule is now more marked ( $P=0.08$ against 0.18 ), but there is less evidence of there being an appreciable difference between the combined-treatment (normal-steroid) schedule and the combined-treatment (highsteroid) schedule ( $P=0.14$ against 0.05$)$.

TABLE X.-Adiusted Differences Between Estimated Median Survival Times for 40 Patients with Lymphoblastic Leukaemia

\begin{tabular}{|c|c|c|}
\hline $\begin{array}{l}\text { Treatment* } \\
\text { Comparison }\end{array}$ & $\begin{array}{c}\text { Differences between } \\
\text { Medians }\end{array}$ & Probability \\
\hline $\begin{array}{l}\text { Steroid alone-mercaptopurine alone } \\
\text { ("ormal" steroid) } \quad \text { treatment } \\
\text { Steroid alone-combined treatment } \\
\text { (high steroid) } \\
\text { Mercaptopurine alone-combined treat- } \\
\text { ment (normal steroid) } \\
\text { Mercaptopurine alone-combined treat- } \\
\text { ment (high steroid) } \\
\text { Combined treatment (normal steroid) } \\
\text { combined treatment (high steroid) } . .\end{array}$ & $\begin{array}{r}+158 \cdot 2 \\
+112 \cdot 5 \\
+181 \cdot 3 \\
-45 \cdot 7 \\
+23 \cdot 1 \\
+68 \cdot 8\end{array}$ & $\begin{array}{l}0.08 \\
0.24 \\
0.03 \\
0.32 \\
0.60\end{array}$ \\
\hline
\end{tabular}

- Mercaptopurine: $2.5 \mathrm{mg}$./kg. of body weight daily. Normal steroid/steroid alone: $40 \mathrm{mg}$. daily. High steroid: $250 \mathrm{mg}$. daily.

$t$ Probability of an occurrence due to chance of an absolute difference as large as or larger than that observed.

\section{Discussion}

The main result of these two trials is that there is no clear "best" schedule among those we have tried, but the combined treatment with large doses of steroid is definitely the worst. Patients on steroid alone have, in both the myeloid and the lymphoblastic series, done somewhat better than those on mercaptopurine alone or on the combined treatment with normal doses of steroid. Differences between these last three treatments were, however, significant only in the myeloid series, when both steroid alone and mercaptopurine alone were superior to the combination of the two $(P=0.03$ and 0.05 respectively). The treatment of choice among a still unsatisfactory lot is therefore steroid alone. It must be noted, however, that in these trials adherence to the different schedules was required only for the first eight weeks of treatment (see p. 1383, paragraph 3), and even this was not always complete. The differences between the results obtained with the four methods of treatment are therefore likely to have been blurred by the use of additional treatments during the final stages of the disease.

We must note also that in our analysis of the results in the myeloid series we ignored patients who died within three days of the start of treatment ; we did not believe that their survival could have been affected by the treatment, and their inclusion would have created an apparent disadvantage for treatment with mercaptopurine alone. If this argument is not accepted

TABLE XI.-Adiusted Differences Between Estimated Median Survival Times for All Patients with Myeloid Leukaemia

\begin{tabular}{|c|c|c|}
\hline $\begin{array}{l}\text { Treatment } \\
\text { Comparison }\end{array}$ & $\begin{array}{c}\text { Difference between } \\
\text { Medians }\end{array}$ & Probabilityt \\
\hline $\begin{array}{l}\text { Steroid alone-mercaptopurine alone } . . \\
\text { "o combined treatment } \\
\text { (normal'steroid) } \\
\text { Steroid alone-combined treatment } \\
\text { (high steroid) } \\
\text { Mercaptopurine alone-combined treat- } \\
\text { ment (normal steroid) } \\
\text { Mercaptopurine alone-combined treat- } \\
\text { ment (high steroid) } \\
\text { Combined treatment (normal steroid) - } \\
\text { combined treatment (high steroid) .. }\end{array}$ & $\begin{array}{l}+19 \cdot 7 \\
+26 \cdot 1 \\
+45 \cdot 2 \\
+6 \cdot 4 \\
+25 \cdot 5 \\
+19 \cdot 1\end{array}$ & $\begin{array}{l}0.001 \\
0.52 \\
0.01\end{array}$ \\
\hline
\end{tabular}

- Mercaptopurine: $2.5 \mathrm{mg} . / \mathrm{kg}$. of body weight daily. Normal steroid/steroid alone: $40 \mathrm{mg}$. daily. High steroid: $250 \mathrm{mg}$. daily. + Probability of an occurrence
as or larger than that observed. and the data are re-analysed, including these patients, the conclusions would have to be slightly modified. The estimated median survival times (after allowing for differences in presenting features) are now: steroid alone 64.9 days, mercaptopurine alone 45.2 days, combined treatment with normal doses of steroid 38.8 days, and combined treatment with high doses of steroid 19.7 days. The corresponding differences between pairs of treatment groups are given in Table XI. On this basis the combined treatment with high doses of steroid is still clearly the worst. The use of steroid alone is still associated with the longest survival, but there is now less evidence to suggest that either normal doses of steroid alone or mercaptopurine alone are superior to their combined use from the beginning.

If it is accepted that the inferior results in the myeloid series with the combined treatment with normal doses of steroid are due to a real difference in the efficacy of the treatment schedules the possibility has to be considered that they may result from a summation of the harmful effects of the two drugs. We have, however, no direct evidence that they acted together in this way, and the mode of death in the overwhelming majority of patients was simply and directly related to uncontrollable blast-cell proliferation. Moreover, there is no evidence of any additive harmful effect in the lymphoblastic series, in which the results obtained with the combined treatment were intermediate between those obtained with steroid alone and mercaptopurine alone (Fig. 6).

The results of the present study have been analysed in greater statistical detail than usual in clinical trials. Ready access to electronic computers made it easy to use the method of regression analysis, and advantage has been taken of the opportunity provided by the careful examination of so many patients to improve our knowledge of the natural history of the disease. In the event, the results have done more to expose ignorance than to add to positive knowledge of prognostic features. Apart from confirming that a high blast-cell count $(25,000$ or more per c.mm.) carries a high risk of early death in myeloid leukaemia, the main conclusion is that all the presenting features, normally regarded as being of prognostic importance, taken together, are capable of accounting for only about $10 \%$ of the individual variability of survival times. Clearly the features that were analysed can have only a very indirect relation to the underlying biological process.

Comparison between the presenting features in the myeloid and lymphoblastic series has, with one exception, confirmed the results reported by Bernard et al. (1964) in France, despite the fact that their diagnostic criteria were not identical with ours and that their myeloid group included some cases described as undifferentiated acute leukaemia. The exception was that in our series a low platelet count was more often found in the lymphoblastic leukaemia series than in the myeloid.

In our first report (M.R.C., 1963) we emphasized that one maior difference between the myeloid and lymphoblastic diseases was that the frequency of remission in the latter was some four times higher than in the former, and that the superior survival in the lymphoblastic disease was a direct result of this ; but we also showed that some patients with myeloid leukaemia survived for long periods without ever remitting. To discover whether remission prolongs life it would be necessary to discard from the analysis all patients who died within the period necessary for the fulfilment of the temporal requirements for the occurrence of remission. If this were not done the patients who remitted would inevitably have a longer survival, because they must have survived a defined minimum period before qualifying as having remitted, as well as the preceding period in which the remission was induced. In the myeloid series the number of complete remissions was too small to make such an analysis worth while. We have not therefore analysed survival in relation to remission. It should be noted, however, that of the 39 patients with myeloid leukaemia six remitted after receiving only steroid therapy. 


\section{Third Trial in Acute Leukaemia}

Treatment with large doses of steroid was abandoned when the results of our first trial clearly showed it to be harmful. The comparison of the remaining treatment schedules has shown no such clear distinction between them, but because of the slight superiority of treatment with steroid alone we have used this as the basis for treatment in our current trial. All patients now begin treatment with prednisone at a daily dose of $40 \mathrm{mg}$. The treatment is continued until a response has been obtained, or until it is clear that the patient is not responding. Antimetabolite therapy is started when the patient relapses ur has failed to respond to prednisone. The drug then used is either mercaptopurine, administered at the standard dosage of the previous trials, or azathioprine (Imuran) at a daily dose of $4 \mathrm{mg} . / \mathrm{kg}$. of body weight. No attempt is made to vary the treatment policy according to the cytological diagnosis, because in the first and second trials the slight superiority of steroid therapy at normal dosage was evident for both the main types of the disease.

\section{Summary}

A controlled trial of treatment for acute leukaemia in adults (aged 14 years and over) has been carried out, and the results have been analysed in conjunction with those of a previous trial in which two of the three treatment schedules used were the same. Comparisons have been made between the relative effects of initial treatment with (1) prednisone alone $(40 \mathrm{mg}$. a day), (2) mercaptopurine alone $(2.5 \mathrm{mg} . / \mathrm{kg}$. of body weight daily), (3) the combination of mercaptopurine $(2.5 \mathrm{mg} . / \mathrm{kg}$. of body weight daily) and prednisone at normal dosage $(40 \mathrm{mg}$. a day), and (4) the combination of mercaptopurine $(2.5 \mathrm{mg} . / \mathrm{kg}$. of body weight daily) and prednisone at high dosage $(250 \mathrm{mg}$. a day).

The patients were classified in two broad cytological types : lymphoblastic (40 patients) and myeloid (210 patients). Eight patients could not be classified in either group and were excluded.

Comparison of the patients in the different cytological groups showed that lymphoblastic leukaemia tended to occur at younger ages than myeloid leukaemia, and that these patients tended to have lower platelet counts $(45 \%$ under $25,000 / \mathrm{c} . \mathrm{mm}$. against $20 \%$ ), more spleen enlargement ( $75 \%$ palpable spleen against $37 \%$ ), and more lymph-node involvement $(68 \%$ enlarged nodes against $39 \%$ ). Swollen gums were complained of by $9 \%$ of patients with the myeloid type leukaemia, all being cases of monocytic leukaemia.

Fourteen features of the patient and of the disease process were recorded before treatment was begun, and the relationship between these features and the duration of survival was examined. In the myeloid series a high blast-cell count was closely correlated with the risk of early death; $27 \%$ of patients with counts of $25,000 / \mathrm{c} . \mathrm{mm}$. or more died within three days of the start of treatment $(15 / 56)$, compared with $1.5 \%$ of patients with lower counts $(3 / 154)$.

No other feature was strongly related to survival in either cytological series.

Among the patients with myeloid leukaemia who survived more than three days the neutrophil count was positively associated, while age was negatively associated with survival ; when allowance was made for these two features the blast-cell count was negatively associated with survival.

Among the patients with lymphoblastic leukaemia palapable enlargement of the spleen was positively associated with survival; when allowance was made for this the platelet count also had a small positive correlation

In the myeloid series (excluding patients who died within the first three days and after adjusting for the effect of pre-treatment differences) the longest median survival period was in the group treated with steroid alone (70 days), followed by the mercaptopurine group (62 days), and the combined-treatment group with normal doses of steroid (41 days); when mercaptopurine was combined with large doses of steroid the median survival was much shorter ( 21 days). The differences between the first three treatment groups and the last (combined-treatment, highsteroid) were statistically very significant; the differences between the first two groups and the third (combined-treatment, normal-steroid) were barely so.

In the lymphoblastic series the longest median survival time (after adjusting for the effect of pre-treatment differences) was also found in the group treated with steroid alone (235 days), and the shortest time in the group treated vith mercaptopurine combined with high doses of steroid (53 days). For these patients, however, the order of the intermediate groups was reversed-the median survival time being 122 days for mercaptopurine combined with normal doses of steroid and 76 days for mercaptopurine alone. The numbers in each treatment group were small, and the only difference that was statistically significant was that between the steroid-alone group and the combined group with high doses of steroid.

\section{Appendix : Transformation of the Survival-Time Scale}

To assess the significance of the observed differences in the survival curves for the four treatments, especially when taking into account pre-treatment differences, the analysis of variance (or covariance analysis) is our most powerful statistical tool. Some conditions are, however, required for the analysis of variance to be valid; the most important of these are that the response variable (in our case the survival time or some transformation of it) should be " normally" distributed, and that the variances of the distributions should be the same even if the means are different (see Box and Cox, 1964, for a full discussion). To satisfy these conditions Box and Cox (1964) suggest that the response variable $z$ be chosen from the family of transformations,

$$
z=\left(y^{\mathrm{a}}-1\right) / a
$$

where the value of the constant $a$, which defines the actual transformation, is calculated from the data by the method of maximum likelihood (see Box and Cox, 1964, for details of methodology). It may be noted that this family of transformations include as particular cases most of the transformations commonly employed-for example, (1) with $a=1$ we have $z=y-1$, which is equivalent to leaving the data in its original form, (2) with $a=0$ we have $z=\log (y)$, (3) with $a=0.5$ we have $z=(\sqrt{ } y-1) / 0.5$, which is equivalent to a simple square-root transformation.

It should be mentioned that Box and Cox (1964) suggest that the constant $a$ in the transformation should be calculated allowing not only for possible treatment differences but also far the effect of the pre-treatment factors (by using a multiple regression equation). We have allowed for the former but not for the latter, as this would have involved a large increase in computation, while the possible gain could only have been marginal, since the pre-treatment factors are only slightly correlated with prognosis.

For the myeloid series of patients surviving more than three days $a=-0.085$; for the lymphoblastic series of patients $a=$ 0.265 ; and for the myeloid series taken as a whole $a=0.082$.

\section{REFERENCES}

Bernard, J., Boiron M., Manus, A.. Levy, J. P., and Lellouch, J. (1964) Nat. Cancer Inst. Monogr., No. 15, p. 359.

Box, G. E. P., and Cox, D. R. (1964). F. roy. statist. Soc. B, 26, 211. Medical Research Council Working Party on the Evaluation of Differen Methods of Therapy in Leukaemia (1963). Brit. med. F., 1, 7, 1541. 